\title{
Rural Development through E-Governance Initiatives in India
}

\author{
Ambika Bhatia ${ }^{1}$, Chhavi Kiran ${ }^{2}$ \\ "Associate Professor, Punjabi University Regional Campus, Mohali, India) \\ ${ }^{21}$ Research Scholar, Punjabi University, Patiala, India)
}

\begin{abstract}
Amongst the emerging Asian Economies, India is a nation with $70 \%$ of population living in rural areas which casts pressure on Government to focus more on development of Rural India. ICT acts as a provider of major opportunities to rural livelihoods and contributes towards poverty reduction. Productivity of rural areas can be enhanced by usage of ICT. Through various E-Governance initiatives like E-Choupal, Akashganga, Gyandoot, Tata Kissan Kendra, Kissan Call Centres etc., Government of India has ambitious objective of transforming the interaction of citizens with government in an electronic form. Through this, Government can ensure more transparency and better administration. Through this paper an attempt has been made to identify various building blocks that have led to rural development through various ICT initiatives.
\end{abstract}

Keywords: digital divide, digital India, e-governance, ICT, rural development.

\section{INTRODUCTION}

In today's era Information and Communication Technologies (ICT) has brought remarkable change in the lives of people in every respect also enabling government to deliver better services even at remotest corners of the country. Various ICT applications have been designed specifically for the people residing in rural areas of the country. Ministry of Rural Development (India) has taken various initiatives at different levels by way of strengthening the ICT infrastructure to provide opportunities, information and easy access of the rural development Schemes to all citizens in rural India. Such developments have facilitated access to innumerable services and information in a very economical manner in a scenario where the cost of accessing information has been a biggest hurdle for the poor farmers. Through ICT, several e-governance initiatives have been adopted which have ultimately proved to be a major contributor in rural development.

\section{OBJECTIVES}

- To identify the building blocks towards rural development through ICT.

- To study different E-governance initiatives in India.

\section{RESEARCH METHODOLOGY}

The paper is based on secondary data and data is procured from published sources like the websites of Ministry of Rural Development, research papers, books and periodicals and newspaper reports.

\section{RURAL DEVELOPMENT}

India is a nation with $69.8 \%$ of total population lives in rural areas [1]. With such large rural population government is required to make concrete efforts for the development of Rural areas. Undoubtedly Government of India has made considerable efforts like Digital India campaign initiated in 2015 to reduce the digital divide and ICT has proved to be a tool for its successful implementation. As per Chambers rural development is a strategy which enables people to benefit themselves and their families by fetching more of what they need [2]. Singh defines Rural Development as a process which leads to sustainable improvement in quality of life of poor people residing in rural areas [3]. Table 1 highlights that even though the percentage of rural population in India is decreasing since last two decades but still it accounts for major proportion of total population. In 1991 the percentage of rural population was $74.3 \%$ which reduced to $72.2 \%$ in 2001 leading to $69.9 \%$ in 2011 . This decrease in rural population could be understood as an indication that there is a need to provide better facilities in rural areas. It indicates that more people are migrating to urban areas in past two decades I order to get access to better facilities and services available in cities. 
TABLE I: Population of India (In Crores)

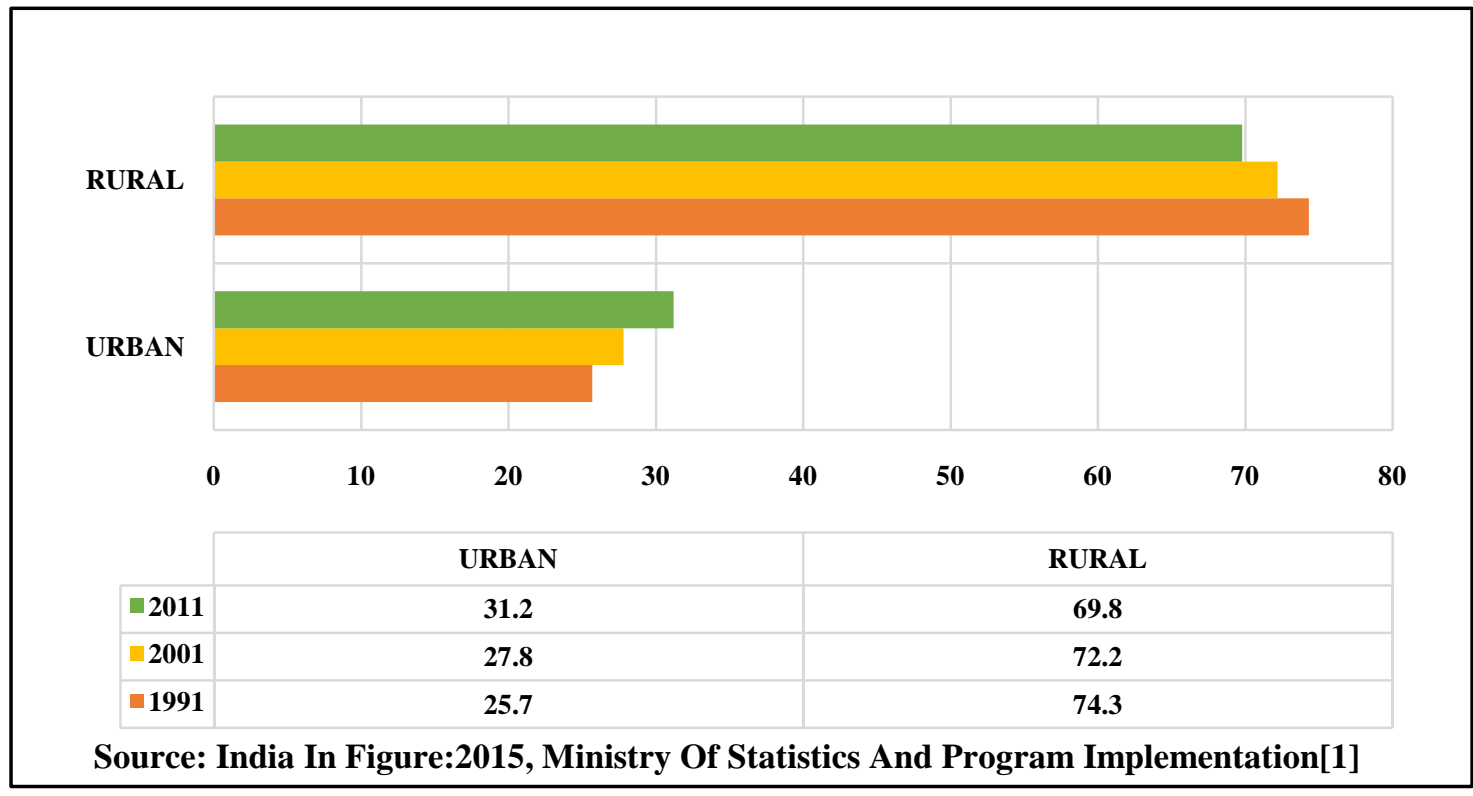

5.1

\section{BUILDING BLOCKS TOWARDS RURAL DEVELOPMENT THROUGH ICT}

INCREASE IN INTERNET USER BASE IN RURAL AREAS

As citizens of rural areas get more educated about the convenience they can derive from biggest revolution of 'internet access', they'll be able to explore more and stay well connected with growing trends. Rural users as a percentage on internet population will rise from $29 \%$ in 2013 to 40-50\% in 2018. (BCG Analysis, 2015). Mobile internet users are likely to constitute $60-70 \%$ of the total online population.

TABLE II: The 2018 Internet Population will be older, more rural, more gender balanced

\begin{tabular}{|l|l|l|}
\hline & \multicolumn{1}{|c|}{$\mathbf{2 0 1 3}$} & \multicolumn{1}{|c|}{$\mathbf{2 0 1 8}$} \\
\hline OLDER & $60 \%$ under 25 & $54 \%$ over 25 \\
\hline RURAL & $29 \%$ rural & $40-50 \%$ rural \\
\hline $\begin{array}{l}\text { GENDER } \\
\text { BALANCES }\end{array}$ & $\begin{array}{l}2.6 \text { men online for every woman } \\
\text { online }\end{array}$ & $\begin{array}{l}1.9 \text { men for every woman among 18-24 years' } \\
\text { old }\end{array}$ \\
\hline \multicolumn{2}{|l|}{ SOURCE: SHAH et al, BOSTON CONSULTING GROUP ANALYSIS, 2015 [4] } \\
\hline
\end{tabular}

\subsection{SPeEch-B ASed Automated Commodity PRices HelPline:}

All the e-governance projects initially initiated used English as the medium of communication. But in rural areas where the people are not at all educated and cannot read and write their native language dealing in English is definitely a problem. This is also a cause of failure of many e-governance projects. A very good initiative has been taken by consortium of seven institutions (IIT-M, IIT-K, IIT-B, IIT-G, IIIT-Hyd, TIFR \& CDAC-Kol) and coordinated by IIT Madras. A speech based automated commodity prices helpline for AGMARKNET has been introduced in six different Indian languages. In this they have developed an automated system from which the farmers can inquire about the latest price of agricultural commodities in their own native language. 


\subsection{INCREASING LITERACY RATE}

TABLE III: Literacy Rate (Rural)

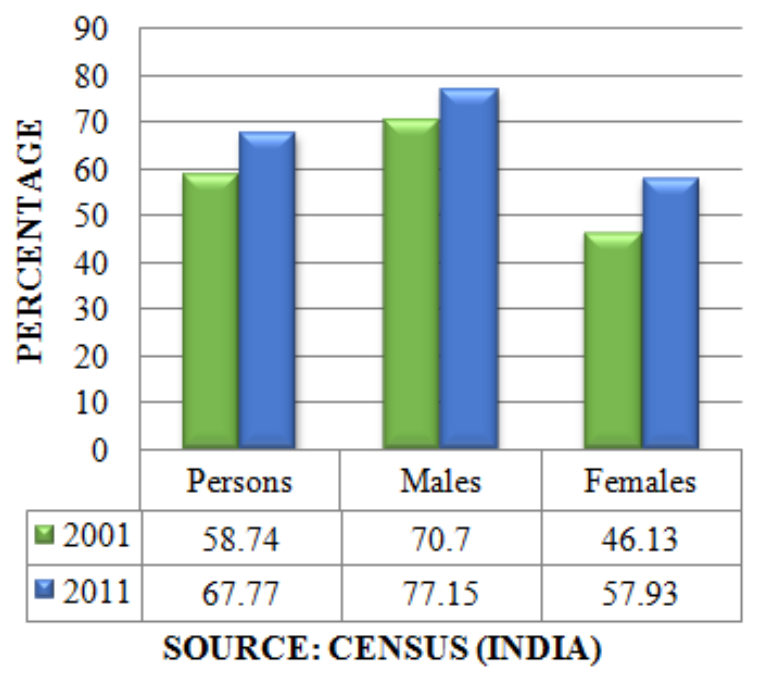

From table 3 we can infer that literacy rate among rural males above 7 years of age has increased by $6.8 \%$ from 2001 to 2011 and among rural females has increased by $11.8 \%$. So it is a supportive element for the implementation of various e-governance initiatives and Digital India campaign as it aims at providing internet access to people residing in rural areas for which more literates will be required.

\section{E GOVERNANCE}

Since the time India has adopted e-governance as a part of its policy, E-Governance has witnessed a productive advancement. E-governance is using information communication technologies in order to improve the interactions within the government departments and between citizens and government [5]. Prabhu states that the motto behind E-Governance is to provide SMART (Simple, Moral, Accountable, Responsible and Transparent) government [6].

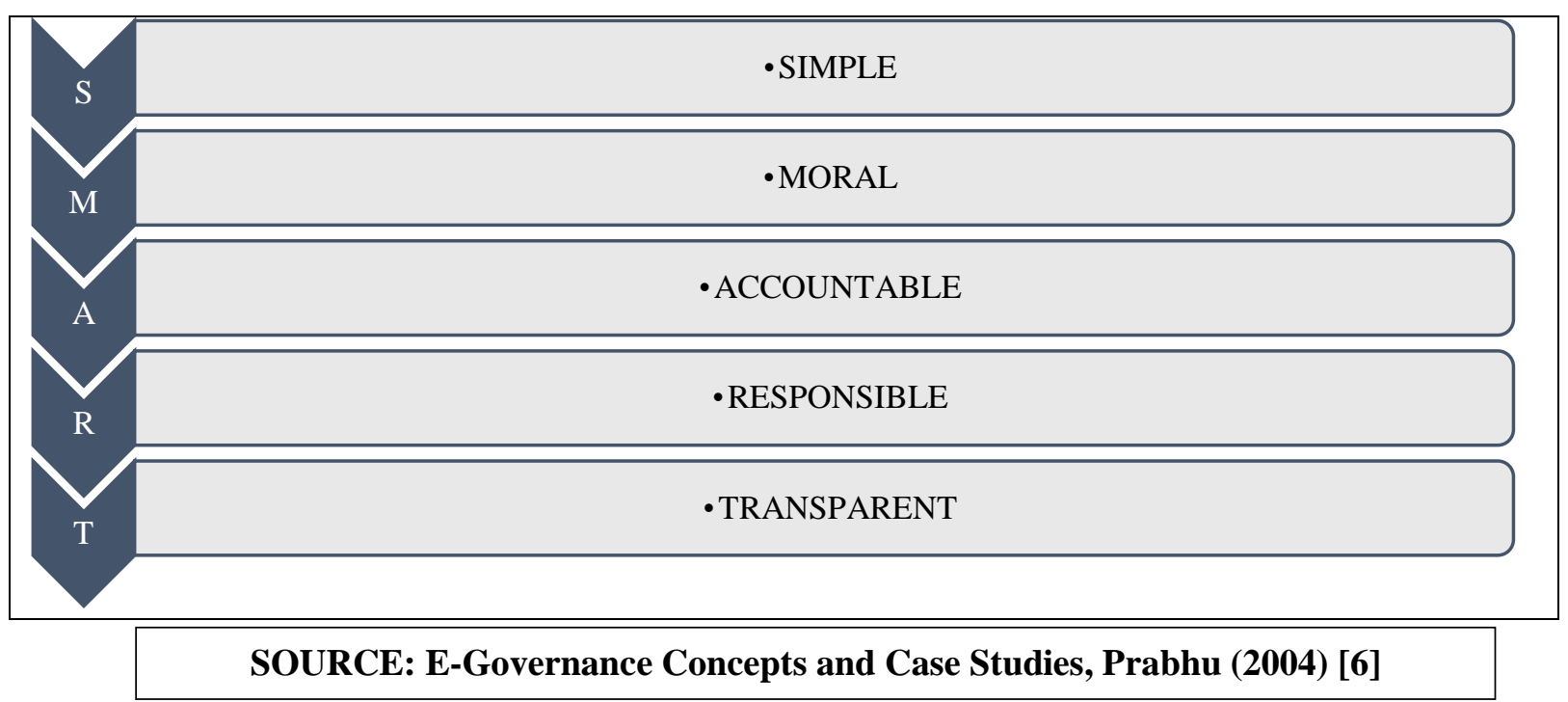

Fig. 1: Motto behind E-Governance (Smart Government)

Abramson and Means define E-Government as the electronic interaction (transaction and information exchange) between the government, the public (citizens and businesses) and employees [7]. World Bank has defined E-Government as the usage of information technologies by various government departments and 
agencies that have the ability to modify the relations among people, businesses and the government. Such technological advancements are capable of providing numerous benefits like improvised delivery of services to citizens and businesses, better empowerment of citizens, reduced levels of corruptions and efficiency in working styles adopted by government [8]. The concept of E-Governance is not just used in India but is renowned globally specifically in China where lot of open source soft wares are available [9]. E-Governance initiatives have not just benefitted people by providing market information economically but have also helped in the uplift of level of education of students living in rural areas through various educational projects. Definitely these projects are need of the hour and there is a vast scope for introduction of such projects in to develop rural areas [10].

\subsection{BACKGROUND AND GLOBAL ERA OF E-GOVERNANCE}

On one hand E-governance initiatives have flourished well in many parts of the world while on the other hand failure stories abundantly reflect that such initiatives with development perspectives have not yielded encouraging results. Estimates indicate that 35 per cent are total failures, 50 per cent are partial failures, and 15 per cent are successes in developing and transitional countries [11]. These failures are due a gap between the phase of designing a project and the final phase of implementation. Considerable differences have been seen in the way the projects are being implemented. Despite such unpromising outcomes, e-government initiatives in developing countries have grown to a level of recognition among government agencies. Heeks and Molla has given ICT 4D activity (Figure 2) which highlights that initially the major issue with regards to E-Governance was readiness where it was difficult to implement such initiatives due to lack of awareness, more digital divide and lack of infrastructure. With the passage of time, the problem of availability of resources for carrying out the E-Governance Projects came up. Once with heartfelt efforts of Government these first two issues were addressed, a new concern for usage of services provided to citizens under these initiative cropped up. People were finding it hard to believe that they can have such easy access to all their needs and wants. Then after 2010 the major concern was impact of various E-Governance Projects initiated in terms of efficiency of working, effectiveness with regards to time and equity [12] [13].

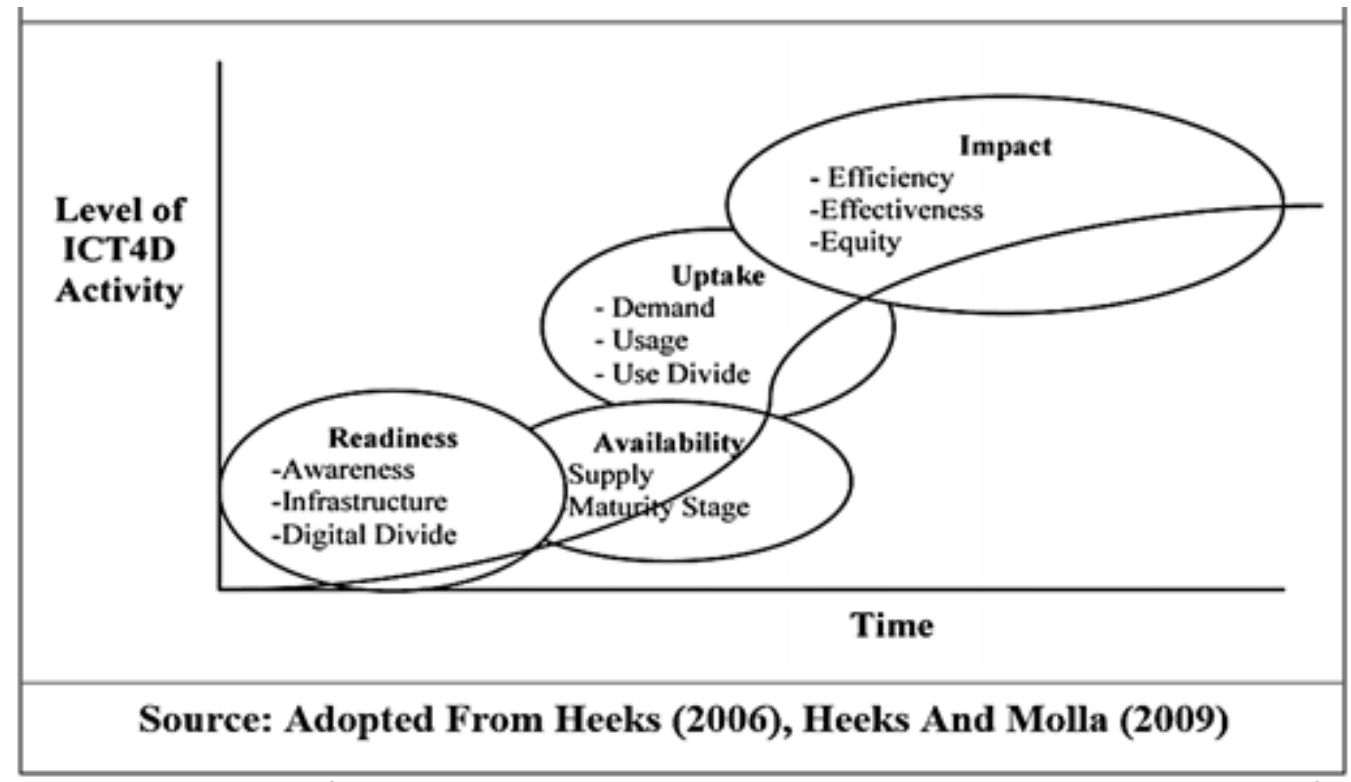

Fig. 2: Changing E-Government Issues over time.

E-governance projects have reached the level of maturity in many countries usage in many countries has evolved to the level of maturity. But however, usage of such services has been a challenge. Wilson states that in a developing economy like India, ICT has progressive applications in health, education, governance, environmental monitoring, human rights promotion, economic growth and other areas [14]. A research 
conducted by Annamalai and Rao have proved that there has been a substantial reduction in transaction costs after adoption of automated supply chain management models for selling agriculture [15].

\section{Digital India CAMPAign}

Communicating with the citizens has been a big challenge for the government of India with extensive geography, immense population, and vast linguistic \& cultural diversity. The most efficient way for communicating with all the people of world's largest democracy is through connectivity at a Digital platform. Government of India has aimed at effectively using the improvements in ICT to reduce the digital divide in the country. Digital India is centered on three vision areas [16]:

\subsection{Digital INFRASTRUCTURE AS A UTILITY TO EVERY CITIZEN}

The government is planning to provide high-speed internet connectivity to 250,000 Gram Panchayats, which will be a core utility for digital inclusion. The citizens will be provided with a digital identity which will be unique, lifelong, online, and valid. There will be easy access to Common Service Centers and a shareable private space for every citizen on a public cloud.

7.2 GOVERNANCE AND SERVICES ON DEMAND

Under this vision, all the government departments will be seamlessly integrated with high-speed optical fiber, that will improve inter-operability of these departments and will result in real-time service delivery from online or mobile platform. Apart from this, the government is planning to make all citizen entitlements portable through cloud for easy and country-wide access and to digitally transform the services for improving ease of doing business in India. The government also plans to use the power of Geographic

Fig. 3: Pillars of Digital India Campaign

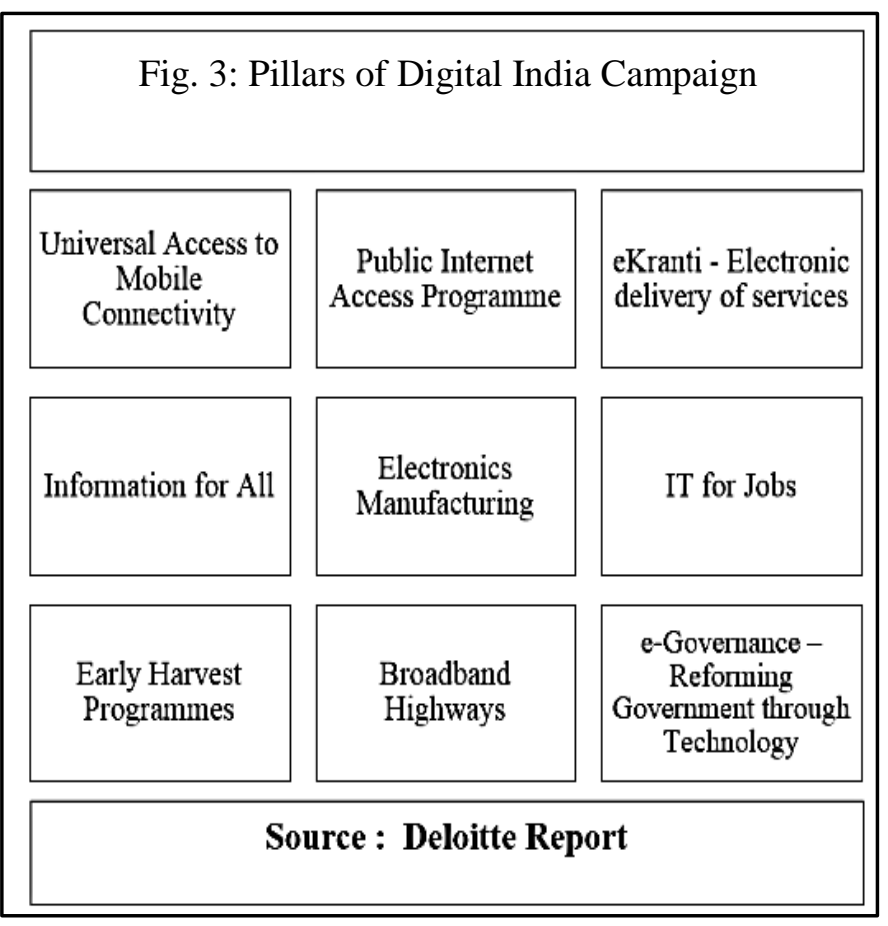
Information Systems (GIS) for decision support systems \& development making financial transactions electronic and cashless.

\subsection{Digital EMPOWERMENT OF CITIZENS}

This vision is to empower citizens of India through digital literacy and universal access to digital resources. Like all documents or certificates to be available on cloud and in Indian languages. Government also wants to provide collaborative digital platforms for participatory governance.

The digital platform can enable more creative and service-oriented business models that create employment opportunities. The Digital India project itself will create employment opportunities for 17 million people directly or indirectly which will help in fighting against unemployment problems in India. Government has planned to give IT training to 100 million students in smaller towns and villages as employment opportunity in IT sector is very high in India.

\section{1}

VIII. RURAL E-GOVERNANCE INITIATIVES IN INDIA

COMPUTERIZED RURAL INFORMATION SYSTEM PROJECT [CRISP]

CRISP aimed at assisting the District Rural Development Agency [DRDA] in observing the exercise of poverty alleviation programmes through Computer based Information System. So far four versions of CRISP application software packages have been developed. Rural Soft was the fourth version. Rural Information endeavors marked the beginning of e-Governance in India. One such initial effort was Rural soft 2000. Through 
Rural soft 2000 common man can access all information on government portals and it also enabled government to monitor workings of various agencies. The latest in the series is Rural Soft, which is a scalable solution that helps in web based monitoring of the poverty alleviation schemes. It has been implemented in 15 districts of the country, which have been wired using state-of-the-art VSAT (satellite based) network by the ministry.

\subsection{NEGP \& NIC}

For the success of e-governance, Government launched National e-governance plan and with the help of National Informatics Centre set up a central repository for all e-governance initiatives.

- NeGP: National e-Governance Plan was launched with the following vision:"Make all Public Services accessible to the common man in his locality, through common service delivery outlets and ensure efficiency, transparency and reliability of such services at affordable costs to realize the basic needs of the common man." [17] NeGP came up on May 18, 2006 by Department of Electronics and Information Technology (DEIT) and Department of Administrative Reforms and Public Grievances (DAR\&PG). NeGP was set up with 27 Mission Mode Projects (MMPs) and 8 components. It was specially designed for rural areas and for the easy access of the services provided by NeGP State Wide Area Network (SWAN) and Common Service Centre (CSC) was set up.

- NIC: NIC is a part of the Indian Ministry of Communications and Information Technology's Department of Electronics \& Information Technology and came up in 1976. It is a website designed for all the e-governance initiatives taken by government at one place. This includes blocks, districts, state government and central government. The ICT network of NIC is called NICNET.

\section{E-Governance Projects In RURAL India}

\subsection{E-CHOUPAL}

India has witnessed massive industrialization in past decade but still agriculture is a dominant occupation in India. The farmers are often exploited by unreasonable intermediaries at every stage involved in the process of selling their produce to the final consumer. Such intermediaries or agents add their profit margin, try to hinder the market information. In order to cater to such problems, the International Business Division of Indian Tobacco Company (ITC-IBD) initiated a step called e-Choupal (which means a village meeting place). Under this initiative various e-Choupals were set up in around 6500 villages by 2012 and each e-Choupal was equipped with a PC, internet connection, printer and Uninterrupted Power Supplies (UPS). Through this the managers at ICT-IBD could fetch cheapest raw materials directly from the farmers and farmers were also able to benefit out of this as there was no intermediary involved. Indian Tobacco Company Ltd. has added 7 new EChoupals a day and plans to scale up to 20,000 E-Choupals covering 100,000 villages in 15 states, servicing 15 million farmers by 2020 [18].

\subsection{GYANDOOT}

Civil servants consulted various

Gram Panchayats in Dhar district in Madhya Pradesh. The project was started in January,2000 and named as Gyandoot. Gyandoot is very beneficial as it is economical and is owned by rural intranet system that is Soochnalaya, as it helps to fulfill the needs of villagers in the district. Rural youth manage 35 such centres which were established since January, 2000. The unemployed educated youth were trained and they ran the Soochnalaya and are known as Soochaks. They provide various types of services information related to agriculture, education, health,

FIGURE 4: E-GOVERNANCE PROJECTS IN

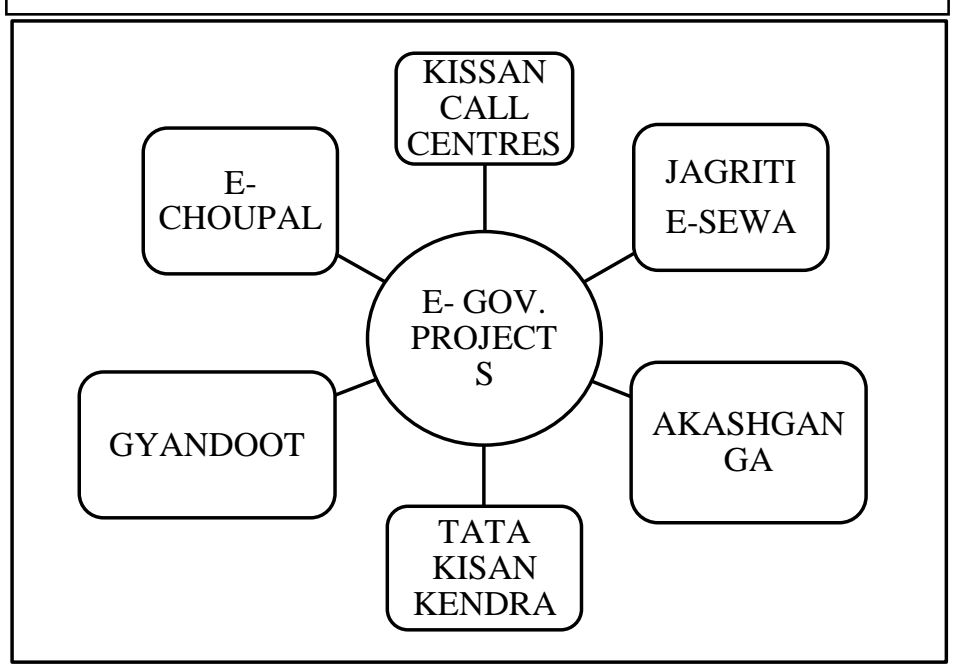
issues related to women, information about market and user fee is charged for all this. They further serve in 
making application for the services provided by the district headquarter for ownership of land. Soochnalaya are connected with dial-up lines through internet. Above 600 villages and approximately $50 \%$ of the total population of a district are covered by the network of 31 such Kiosks [19].

TABLE IV. Bottlenecks in E-Choupal and Gyandoot Projects

\begin{tabular}{|c|c|c|c|}
\hline Project & Operational Bottlenecks & Economic Bottlenecks & Personnel Bottleneck \\
\hline E-Choupal & $\begin{array}{c}\text { Infrastructure provided to } \\
\text { "sanchalak" was outdated. }\end{array}$ & $\begin{array}{c}\text { Lack of financial resources } \\
\text { to procure infrastructure. }\end{array}$ & $\begin{array}{c}\text { Challenges with regard to } \\
\text { provision of technical } \\
\text { education to freshers in rural } \\
\text { areas. }\end{array}$ \\
\hline Gyandoot & $\begin{array}{c}\text { Power breakdown interrupts } \\
\text { working and network gets } \\
\text { disconnected. }\end{array}$ & $\begin{array}{c}\text { High operation costs due to } \\
\text { multiple services rendered. }\end{array}$ & $\begin{array}{c}\text { Difficulty in getting } \\
\text { technically skilled youth in } \\
\text { remote areas. }\end{array}$ \\
\hline \multicolumn{2}{|c|}{ Source: E-Government Milestones in Rural India: Eagro Aspects. Salkute, Kohle (2011) [19] } \\
\hline
\end{tabular}

\subsection{JAGRITI E-SEWA}

In the developing nation like India Jagriti E-Sewa is suitable, applicable, reasonable, accessible and sustainable technology. Sometimes old computers are used. this project is used with the help of Dial up telephone lines. Minimum time period is required to change the whole system in any language. These kiosks are located at the center point of village or at the most renowned places of village so that one kiosk can serve minimum 25,000-30,000 villagers. Each kiosk is on franchise basis where the franchisee is an educated young man or ex- serviceman. Sufficient revenue is to be generated by the franchisee to meet the cost [20].

\subsection{AKASHGANGA}

ICT is being used by Akashganga to help the milk producers of rural areas by making cooperative societies and procuring milk and assists in maintaining accounts. In Gujarat first model of Dairy Information System Kiosk (DISK) was implemented at Uttarsanda Dairy Cooperative Society. In this society every farmer is having an individual identification card (plastic card). Their identification is updated in PC when farmers come at Raw Milk Receiving Dock (RMRD) counter. As the milk is emptied in the steel drum the weight of milk can be measured and at the same tie it is recorded in the PC. However, one operator is required for filling the cans and a separator operator for measuring fat content. The new technological development includes weighing balance, microprocessor, printer, milk analyzers and a display to carry out these operations [21].

\subsection{KISSAN CALL CENTRES}

There is change in the language after every $50 \mathrm{~km}$ in India. These call centres are specially made to respond to the issues raised by the farmers in the vernacular language continuously. This scheme was started during April 2002 by the Department of Agriculture \& Cooperation, Ministry of Agriculture. the scheme was launched to deliver the farming villagers about the telecom infrastructure. As most of the villagers are not aware of the latest technological development in the country, these centres are specially designed to serve the purpose of creating awareness among the farmers. Toll free numbers are being provided to the farmers, as the services are to be cost free to all the needy ones. So the agriculture department and line departments, SAUs, ICAR organizations are being instructed by the ministry of Agriculture to do the publicity of toll free numbers of KCC. Publicity material includes posters, charts, training and demonstration Programme etc [22].

\subsection{TATA KISAN KENDRA (TKK)}

In Uttar Pradesh, Haryana and Punjab, TATA Chemical Limited launched Tata Kisan Kendra (TKK). Geographic Information Systems (GIS) helps TKK to tracks basic areas related to farming like soil, ground water and weather. The new software named GIS informs about the roads, buildings and rivers. The data is the form of digital maps and provides information regarding socio-economic, administrative and physical set up. With the help of satellite, images are being processed which further helps to detect insect attacks throughout the state and get estimates of crop. Satellite further helps in upgradation of maps and detecting unproductive farming. 48000 villages are to be served by about 800 franchisees and 40 more kiosks [23]. 
X. Proposed FrameWORK

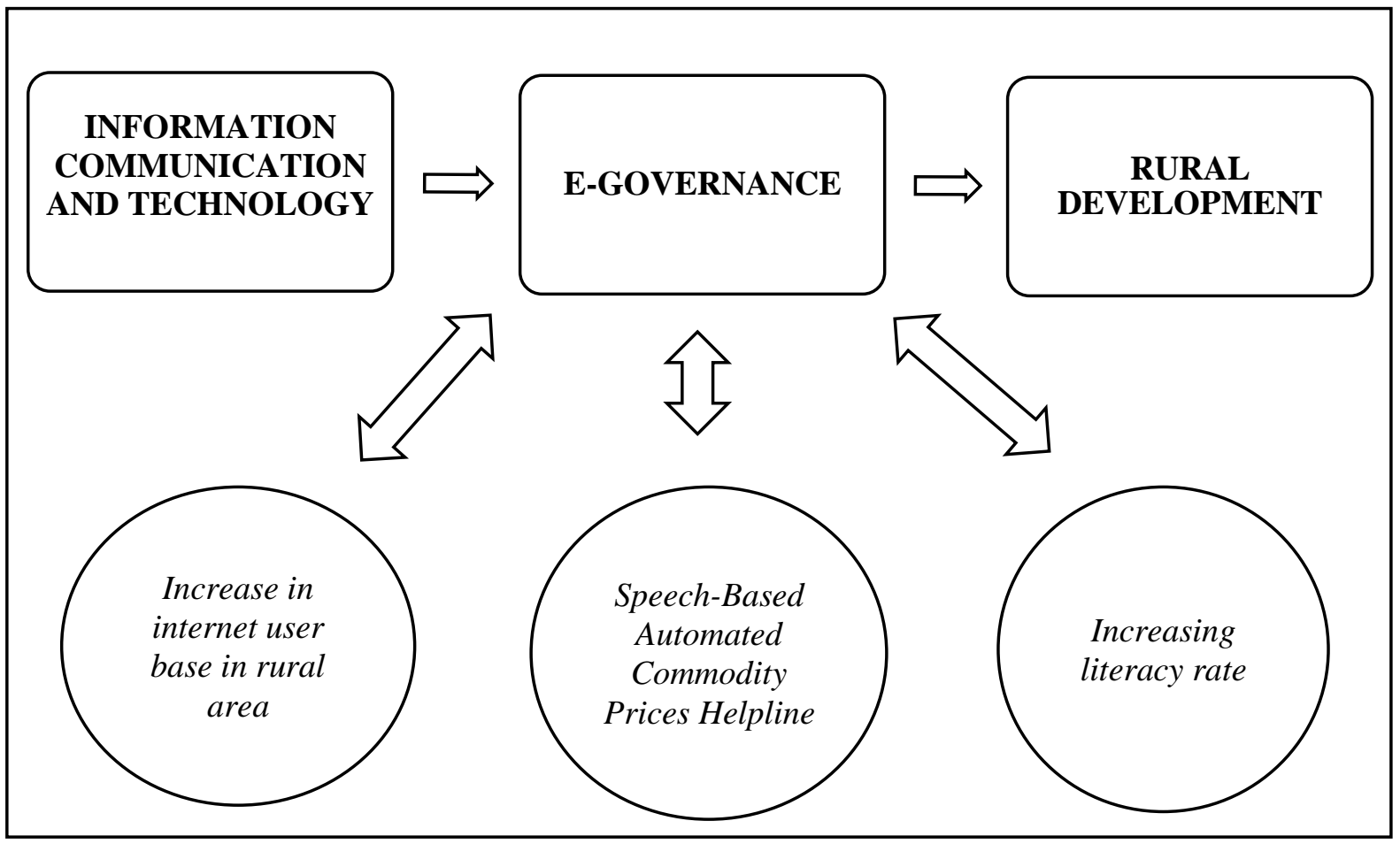

Fig. 5: Proposed Framework

\section{CONCLUSION}

Electronic government (e-Government) is one of the most important ways to bridge the digital divide in developing nations like India. Different initiatives by government through the developments in ICT have helped E-governance to take off since the beginning of millennium. Different building blocks like increasing literacy rate in rural areas, the initiatives like Digital India campaign will help in making the rural people more tech savvy encouraging them to get in contact with Indian government through just a click of button. So in a nutshell it can be concluded that increasing digital literacy with the help of technical advancements are leading and will lead to rural development in India.

\section{REFERENCES}

[1] Government of India , India in Figures 2015, (Ministry of Statistics and Program Implementation, New Delhi: Central Statistics Office, 2015)

[2] R. Chambers, Rural Development - Putting The Last First. (Essex, England: Longmans Scientific and Technical Publishers; New York: John Wiley, 1983)

[3] K. Singh, Rural Development: Principles, Policies and Management ( $\left.{ }^{\text {nd }}\right)$, (New-Delhi, India: Sage Publications, 1999).

[4] A. Shah, S. Bajpai and N. Jain, INDIA@digital.Bharat, (Boston Consulting Group, 2015).

[5] S.Kumar, "E-Governance in India", Imperial Journal of Interdisciplinary Research, 2(2), 2016, 482-491.

[6] CSR Prabhu, E-Governance: Concepts and Case Studies, (New Delhi: PHI Learning Private Limited, 2004).

[7] A.M. Abramson and E.G Means, E-Government, Price water house Coopers Endowment for the Business of Government, (Rowman \& Littlefield Publishers Inc, 2001)

[8] World Bank, Issue Note: E-Government and the World Bank, 2001.

[9] V.B. Singh and N. Yadav, "E-Governance: Past, Present and Future in India", International Journal of Computer Applications, 53(7), 2012, 36-48.

[10] A. H.Rizvi, "A Study Of E-Governance Educational Projects In India”, Global Journal For Research Analysis, 5(1), 2016, 37-38.

[11] H. Misra, "Managing rural citizen interfaces in e-governance systems : a study in Indian context", Proc. $3^{\text {rd }}$ Int. Conf. Theory and Practice of Electronic Governance, 2009.

[12] R. Heeks, "Analyzing the Software Sector in Developing Countries Using Competitive Advantage Theory", Development Informatics Working Paper Series, Manchester: Institute for Development Policy and Management, 25, 2006.

[13] R. Heeks and A. Molla, "Compendium on Impact Assessment of ICT-for-Development Projects", Development Informatics Working Paper Series, Manchester: Institute for Development Policy and Management, 36, 2009. 
[14] M. Wilson, "Understanding the International ICT and Development Discourse: Assumptions and Implications", M.Phil diss., in Development Studies at Oxford, U.K, 2006.

[15] Annamalai, Kuttayan and Rao, "What Works: ITC's e-Choupal and Profitable Rural Transformation Web-Based Information And Procurement Tools For Indian Farmers", Jointly published as "What Works Case Study" by World Resources Institute, Digital Dividend and University of Michigan, 2003.

[16] J.Jani and G. Tere, "Digital India: A need of Hours", International Journal of Advanced Research in Computer Science and Software Engineering, 5(8), 2016, 318-319.

[17] P. Mittal and A. Kaur, "E-governance - A challenge for India”, IJARCET, 2(3), 2013, 1196-1199.

[18] V.R. Salkute and S.R. Kohle, "E-Government Milestones In Rural India: Eagro Aspects", International Journal of Enterprise Computing and Business Systems, 1(2), 2011.

[19] N. Gorla, "Hurdles in rural e-government projects in India: lessons for developing countries", Electronic Government: An International Journal, 5(1), 2008, 91-102.

[20] http://www.akashganga.in/

[21] http://agricoop.nic.in/policyincentives/kisancalldetail.htm

[22] http://www.tatakisansansar.com/ 